sciendo

LEGE ARTIS

Language yesterday, today, tomorrow

Vol. III. No 22018

\title{
FRAME MODELING OF THE CONCEPTS OF LIFE AND DEATH IN THE ENGLISH GOTHIC WORLDVIEW
}

\author{
Anna Prihodko*, Zaporizhzhia National University, Zaporizhzhia, Ukraine \\ Oleksandra Prykhodchenko, Zaporizhzhia National University, \\ Zaporizhzhia, Ukraine
}

*Corresponding author

Prihodko, A. \& Prykhodchenko, A. (2018). Frame modeling of the concepts of LIFE and DEATH in the English Gothic worldview. In Lege artis. Language yesterday, today, tomorrow. The journal of University of SS Cyril and Methodius in Trnava. Warsaw: De Gruyter Poland, 2018, III (2), December 2018, p. 164-203. DOI: 10.2478/lart-2018-0018 ISSN 2453-8035

\begin{abstract}
The Gothic worldview is understood as a manifestation of the environment's reflection in peoples' thoughts, which shows the perception of real and unreal / supernatural worlds in their symbiosis and determines the human's role in it. LIFE and DEATH are universal concepts of culture and most fully they can be shown in the form of frame, the main structural elements of which are ACTANTS, PREDICATES, QUANTIFIERS, PLACE, and TIME.
\end{abstract}

Key words: concept, frame, frame structure, worldview, the Gothic novel, the Gothic worldview.

\section{Introduction}

The cognitive processes in our mind are usually connected with our vision and understanding of the outer world in general and our place in it in particular. The concept as the "major domain of linguistics" (Manerko 2016: 129) despite the great range of attempts to study, classify and denote its place is still popular among modern scientists. It gives a great variety of ways and approaches to study the content and peculiarities not only of language but also of our mind and way of thinking.

One of the most vivid and clear examples of such studies are the analysis of the most antique concepts which exist in human's consciousness - the concepts of LIFE and DEATH 
(Uberman 2016; Uberman 2018). These concepts are universal, which occupy just as important a place in the linguistic as in the Gothic worldview. They are under the investigation of scientists (Kövecses 2015; Lakoff \& Johnson 1980; Panasenko 2012; Prihodko 2015; 2017; Prykhodchenko 2018; Wierzbicka 2010; 2014), who studied their metaphorical structure and their semantic and conceptual character.

The subject of the discussion is the representation of the concepts of LIFE and DEATH in Gothic linguoculture.

The Gothic worldview is realized as a reflection of the environment's understanding in peoples' thoughts, which shows the perception of real and unreal / supernatural worlds in their symbiosis and determines the human's role in it (Ihina 2018; Prihodko 2014). The most vivid implementation of the Gothic worldview is represented in the Gothic novel, which exists as an integral, structured system that continues pre-romantic aesthetics and philosophy (Вацуро 2002: 6). This type of novel was finally formed by the end of the $18^{\text {th }}$ century and it is connected with pre-romantic aesthetics, one of the main theses of which was the interest to Gothic culture.

The understanding of the Gothic novel was very versatile and included not only the medieval style of architecture, but also the gloomy mood of this epoch, the fantasy, knighthood, mysticism, horror, and mystery (Devison 2009; Lovecraft 2009; Punter 1996; 2004). From the point of view of philosophy, the Gothic novel was the reaction to the rationalism of Enlightenment literature. According to the authors of Gothic novels, life was not rational and light, but mysterious and full of fatal puzzles, although still some logical facts were presented there.

The main principles of the Gothic worldview (Вацуро 2002: 11) can be summarized in such a way: the combination of medieval fantasies and modern reality; natural behavior of people in unusual circumstances; the main weapon of Gothic is horror. At 
present the main fact for Gothic culture is the connection of the person and the underworld, of real and supernatural, of life and death.

The basis of the Gothic novel changes thanks to the attempts of the theoretical understanding of the nature of horror: the conception of interrelation between "horror" and "imposing", "real" and "supernatural", "alive" and "non-alive / dead" which are represented via the main dominants of the Gothic worldview - the understanding of the dual character and interconnection of life and death (Бёрк 1979). The main markers of Gothic novels and the representation of the Gothic understanding of the world appeared to be thus: an ancient, half-ruined castle, an ominous owner (a vampire), a heroine who suffers from the horrors and her rescuer.

One of the main topics of Gothic novels became the interrelation between LIFE and DEATH, which is shown in the double nature of the main heroes - vampires, who cross the border between two worlds - real and underworld - and, at the same time, combine the boundary between real and unreal, life and non-alive - death (Horner 1998: 171172).

Among others, the opposition of LIFE - DEATH dominates in the Gothic tradition, and is characterized by the peculiar importance it gains in novels about vampires, where the folklore conception of the evil dead creature is represented ("life-eating maniac" (B. Stoker "Dracula", p. 59)), who is doomed to take lives, threaten the safety and tranquility of living people ("to absorb as many lives as he can" (B. Stoker "Dracula", p. 59)).

DEATH in Gothic novels is understood as the starting point for the new LIFE. Here life cannot escape from the threat of death (Morris 2004: 58). The parallel between the state of life and the state of death is depicted in the Gothic worldview. 
So, Gothic culture is an integral system, which is characterized by the interconnection between some heroes (living and dead creatures, humans and vampires), life and death, by their interrelation and opposition, which reveals the main dominants of the Gothic worldview.

\section{Methodology}

The connection between horrible and frightful lies in the basis of the Gothic novel - in the relation between life and death, pain and satisfaction, real and fiction, natural and supernatural, human and vampire. Therefore, the aim of this article is to define the peculiarities of the frame structure of the concepts LIFE and DEATH in the Gothic worldview. The material under analysis is presented by 15 Gothic novels about vampires of the $19^{\text {th }}-21^{\text {st }}$ centuries.

The aim was achieved with the help of such methods: continuous sampling for inventory and interpretation of the language units; frame modeling for understanding of the semantic structure of the concepts of LIFE and DEATH; descriptive-interpretational method for explanation of the facts after commenting on the material under analysis.

The analysis of the structure, content and the verbalizations of the concepts are based on such theoretical statements: the concept is characterized by its structure, which creates the conditions necessary for its existence in the conceptual domain; the structure of the concept is characterized by flexibility and heterogeneity; it is created with the help of the combination of the cognitive features; in the consciousness of the representative of some culture cognitive features are of equal importance, which is determined by their communicative relevance and influences the nominative density and the means of verbalization of the concept.

\section{Background studies}

There are different points of view on the structure of the concept. Stepanov (Степанов 2004: 46) suggests distinguishing the etymological (historical), actual (well-known) 
and passive (important for some representatives of the culture) layers. Scientists mention that the primary stage of the investigation of the concept is the study of its etymology - "pre-history", i.e. the etymological analysis of the lexeme (Степанов 2004: 48; Турченко 2014: 7). Such an approach gives an opportunity to study the concept in diachrony and explains the presence or absence of some conceptual features (Попова \& Стернин 2007: 98). Karasik (Карасик 2004: 118) extracts the sense, image, and value component of the concept.

There are a lot of other possible conceptions of the structure of the concept. It is necessary to mention, that despite the scientific school and interpretation of the conceptual structure, there is a consolidation of thoughts according to the presence of sense, image and value components in the structure of the concept. This point of view is also represented in our article.

We also distinguish conceptual structure and content. As mentioned above, the structure of the concept is a combination of three main constituents. Cognitive features, which create the conceptual content, correlate with the main components of the structure of the concept. The sense component is formed by the combination of cognitive features, which fulfill the essential characteristics of the object of studying (subject or phenomenon) from the speaker's point of view. The image component is formed with the help of perceptual and cognitive images and combines perceptual (visual, auditory, tactile, flavoring, olfactory) cognitive features, which are created as a result of sensory perception and cognitive features, and are formed as a result of the metaphoric understanding of the conceptualized notion. The value component combines cognitive features, which correspond to the general, emotional, aesthetic evaluation of the speakers. In further representation of the material, we use the term "sense, image and value components of the concept" to determine the components of the conceptual structure and the term "conceptual feature" is used to determine the conceptual content. 
For the interpretation of the structural and content aspects of the concept different methods of analysis are used, which are accepted for that type of conceptual knowledge, with which the scientist deals. To our mind, the most relevant type of analysis for the concepts of LIFE and DEATH will be the frame analysis.

\section{The peculiarities of frame analysis}

In our research the link between the concept and frame is shown via representing the concept as a typical situation, as it denotes the most significant points of its inner structure. Frame is a multi-component concept, which is understood via a combination of its composites as a unity of conventional knowledge about the subject or phenomenon (for example, the SHOP includes the salesman, the customer, the commodity, to buy, a price, etc. (Попова \& Стернин 2007: 119; Prihodko 2014; Prihodko 2016)). Frame is studied as "a notion, information about the world" (Минский 1988: 281-310), "special organization of knowledge" (Fillmore 1985: 230), "as a structure of an informative knowledge" (Селиванова 2000: 101), "as a unit of knowledge, which is organized around the concept" (Болдырев 2001: 5).

Zhabotynska claims that a frame is "one of the methods of structuring the concept's content" (Жаботинська 2006: 180). It is obvious that the reason why frame analysis appears appropriate for describing any situation is the fact that it is a fixed system of parameters, which describe the action or the subject" (Минский 1988: 245). In addition, it is "the convenient tool for discovery of general and concrete characteristics" (Піхтовнікова \& Гончарук 2010: 19).

\subsection{The frame as a typical situation}

The methodology of frame analysis justifies itself while studying the concepts as in some specific linguoculture, for example on the basis of some concrete languages German (concepts POWER (Гайдученко 2009), WAR TIME (Липина 2008), PRIDE and NOBILITY (Сергієнко 2016)), the English language (concepts POWER (Шеховцева 2011), CONFLICT (Ермолаева 2005), MODESTY (Турченко 2014), FIRE and WATER 
(Davydyuk \& Panasenko 2016)), the Russian language (concepts TRUTH and VERITY (Снитко 2008)), and also during comparative studying of the same concept in different linguocultures (Коваль 2010).

It is reasonable to study the frame as the typical situation, which "is connected with the real psychological processes of perception, belongs to the inner layer of the social consciousness and is characterized with the following features: sketchy character, simplicity and stable position in the consciousness of the members of the society" (Селиванова 2000: 101). A frame fixes verbal and non-verbal information in the "structure of the informative data, that was gained empirically, and represents the knowledge about some stereotypical situation and about the text, which describes it" (Минский 1988: 7).

The structure of the frame model contains, first of all, fixed information - the fact, that concerns the state of an object, which is usually thought to be veritable, that is why some scientists limit the frame with the help of predicative-actant bounds, semantic roles of the components of the situation (Селиванова 2000: 100-101; Fillmore 1985; Langacker 1990).

As van Dijk claims, "frames are the fragments of knowledge, which are organized "around" the concept and contain the main typical and potentially possible information, which is associated with this or that concept" (Дейк 1989: 16-18): "what does", "who does", " where and when does", "in what way does" and others. So, the frame combines different types of connections (quantitative, special, temporal, attributive, etc.), which are important for the description of the conceptualized phenomenon.

The frame analysis of the concepts of LIFE and DEATH enables the systematization of the typical actants, predicates, attributes, quantifiers, place and time of the situation. 


\subsection{The frame of the concepts of LIFE and DEATH}

In our work the concepts of LIFE and DEATH are analyzed as situations, that are determined with the help of the dictionary, where such definitions can be found: 'life' - "the course of human events and activities" (Merriam-Webster Dictionary Online) and 'death' - "the event of dying or departure from life" (Merriam-Webster Dictionary Online). While using the main verbalization (life and death) in context and other nominators of the concepts, the informative structure of the concepts LIFE and DEATH is revealed. Let's look at the examples of verbalizations of typical situations: "People lived in Africa millions of years ago; we had a very hard winter last year and some of the plants died unexpectedly" (Oxford Living Dictionaries Online).

These contexts contain parts of the frame model, which are significantly important, show knowledge about situations of life and death, that was obtained empirically, and their appearance in language: actants, which determine the participants of the situation (the doer, the performer, etc.), which are represented via nouns and personal pronouns (people, we, plants); predicates, which depict an action, are represented by verbs (lived, died); direction of place and time of the situation, which are revealed with the help of the concretization of the circumstances of the situation (in Africa, last year, years ago, winter); way of action, which is shown via an adjective (unexpectedly); attributes of the situation, which are revealed via showing the quality of life with the help of an adjective (hard); quantifiers are usually represented by numerals, which specify the duration of life (millions).

The integral part of the structure of knowledge, which is under analysis, are the predicates of the concepts of LIFE and DEATH that are testified by the etymology of these concepts' nomination. Historically, the first denotations are verbal stems (predicatives of the conceptualized situation): in English they are units life and live (< oe. lifian, libban (from 1200) "to be; be alive; have life; continue in life; experience") which take their origin from the Proto-Indo-European verbal root *leip- "to stick, adhere; remain; continue", and units death, die have developed from the Proto-Indo-European etymons 
*dheu- "to pass away; become senseless" + *-thuz "suffix denoting act, process or state" (The Etymological Dictionary of the English Language). So, the verbalization of the concepts of LIFE and DEATH historically correlates with verbal roots and with active and non-active semantics.

Frame analysis of the concepts of LIFE and DEATH ensures the systematization of the typical components of the conceptualized situation: actants (activity, lifeblood, darkness, loss), predicates (live, exist, release, ruin), attributes (living, alive, fatal, lethal), quantifiers (days, nights), place (heaven, grave, tomb), time (nightlife, period, near end, afterlife).

Cognitive structures, which are represented in language, are systematized with the help of frame organization, which makes it possible to determine both most general and most concrete characteristics of the specific concept.

For the investigation of the organization of the concepts of LIFE and DEATH such spheres were singled out: actants, predicates, attributes, quantifiers, place, time, which most vividly represent all the peculiarities of the concepts under analysis, their connection, simultaneous contradiction and unity.

\section{ACTANTS of the spheres of LIFE and DEATH}

Actants of the spheres of LIFE and DEATH represent the connection between the oppositions ALIVE - UNDEAD - NON-ALIVE - DEAD:

- human beings - "Babette's physical life..." (A. Rice "Interview with the vampire", p. 39); "... Erin's and Jordan's own throbbing life..." (J. Rollins "The blood gospel", p. 176); "I knew Helen in a great range of situations, including those we call ordinary life..." (E. Kostova "The historian", p. 131);

- vampires - "I am dead, I am a vampire" (A. Rice "Prince Lestat", p. 71); "...Dracula had become one of the undead ..." (E. Kostova "The historian", p. 99); 
- fictional creatures or monsters: Angel of Death "personification of death" (Oxford Dictionaries online) ("...the Angel of Death will sound ..." (B. Stoker "Dracula", p. 63); "... wings of the angel of death" (B. Stoker "Dracula", p. 134); devil "an evil spirit" (Oxford Dictionaries online) ("...like a devil!" (A. Rice "Interview with the vampire", p. 37); monster "a large imaginary creature" (Oxford Dictionaries online) ("...same ancient monster ..." (A. Rice "Prince Lestat", p. 64);

- the dead - dead "not living" (Oxford Dictionaries online) ("... dead, without ever knowing..." (A. Rice "Prince Lestat", p. 39); corpse "a dead body" (Merriam-Webster Dictionary Online) ("This is death, ... corpse of a woman..." (A. Rice "Interview with the vampire", p. 54).

\subsection{Actants of the sphere of LIFE}

For the characteristics of the sphere of LIFE nouns denoting creatures are used. Here belong such general names with specific (child, the Cardinal) and generalized (human, husbands and children) meaning: "You cleansed this child $<\ldots>$ gave him new life" (S. King "Salem's lot", p. 95); "The Cardinal did not understand life ..." (J. Rollins "The blood gospel", p. 130); "... I should take human blood, for the life essence of human is strongest" (L. Smith "The awakening", p. 31); "No simple life of husbands and children and domesticity" (J. Rollins "The blood gospel", p. 159).

The notion 'human being' is detailed according to the following parameters:

- gender - "... he was in life a most wonderful man" (B. Stoker "Dracula", p. 257);

"... I was the happiest woman <.. > for all the days of my life" (B. Stoker "Dracula", p. 89);

- age - "...taken me to the period of life when I was a little girl..." (P. Cast "Marked", p. 19); "...I lived as a young mortal man" (A. Rice "Prince Lestat", p. 1); 
- degree of relationship, social belonging - "... wife, who lived in New Orleans" (A. Rice "Interview with the vampire", p. 10); "his twin sister..., whose goal in life was to make..." (M. Kruz "Blue bloods", p. 7).

The productivity of the specific countable nouns is explained by the fact that life is the source of the experience of dealing with physical objects, which helps to understand life.

The usage of personal pronouns and of the article 'the' is the evidence of the fact that the sphere of LIFE covers specific phenomena: "Life is all I want" (B. Stoker "Dracula", p. 228); "He came back full of life ..." (B. Stoker "Dracula", p. 195); "She ...lived a moment of life ..." (A. Rice "Interview with the vampire", p. 161); "...upon the life of the entire family" (A. Rice "Interview with the vampire", p. 25); "would not have desired the life of a runaway" (A. Rice "Interview with the vampire", p. 32).

The denotation of the creatures is usually combined with possessive and demonstrative determiners ("I'm fighting for my life ..." (A. Rice "Prince Lestat", p. 147); "... might have saved his life..." (A. Rice "Interview with the vampire", p. 113); "...mortal life became most valuable in this life ..." (A. Rice "Interview with the vampire", p. 22); with the help of which the situational reference and the reflection of the perception of specific, definite, close to the participants of the situation and accessible for understanding, perception, studying and comprehension phenomena of life is realized. It should be noted, that the determinative this is used with the aim of representation of life as close and real ("... I'd tried to escape this life..." (A. Rice "Prince Lestat", p. 16), and that makes an accent on its remoteness or unreality ("That lifetime which might have endured for centuries" (A. Rice "Interview with the vampire", p. 69).

\subsection{Actants of the sphere of DEATH}

Actants of the sphere of DEATH are demonstrated by abstract nouns, which are created with the help of the prefix -ness, have negative meaning and determine 
peoples' understanding of death as of some inapprehensible fact: madness "state of being insane" (Oxford Dictionaries online) ("veil of death or the veil of madness" (A. Rice "Interview with the vampire", p. 32); emptiness "the state of containing nothing" (Oxford Dictionaries online) ("emptiness that was death" (A. Rice "Prince Lestat", p. 64); glassiness "the state of being glassy, lacking liveliness" (Oxford Dictionaries online) ("glassiness of death" (B. Stoker "Dracula", p. 39); harshness "being harsh or rough" (Oxford Dictionaries online) ("harshness of death" (B. Stoker "Dracula", p. 137).

Abstract nouns pain, fear, tremor, shriek are used for the denotation of the fear of DEATH as of something unknown and horrific: "death and pain" (N. Roberts "Morrigan's cross", p. 457); "fear of death" (A. Rice "Interview with the vampire", p. 109); "the death tremors" (J. Rollins "The blood gospel", p. 23); "shrieking death" (J. Rollins "The blood gospel", p. 126).

With the help of anthroponyms and general names in the form of possessive or genitive ("Matias' untimely death" (D. Reynolds "Raphael", p. 74); "...part of Lucy's death ..." (B. Stoker "Dracula", p. 190); "... after a friend's death" (E. Kostova "The historian", p. 34); "old man's death" (B. Stoker "Dracula", p. 134); "... after the death of Vlad Tepes..." (E. Kostova "The historian", p. 217); "... since the death of his father..." (C. Clare "City of bones", p. 225); "... at the death of our brother..." (S. King "Salem's lot", p. 94)) not only information about death of the specific person is given, but also the idea about the inevitability of death for all people is represented ("Magnus ... condemned to death" (D. Reynolds "Raphael", p. 78); "Bathory, bent in death..." (J. Rollins "The blood gospel", p. 229).

The motive of the inevitability of death for an individual is continued in the contexts, to which personal pronouns and possessive determiners are attracted. Structures PRON $_{\text {PERSONAL }}+\mathrm{V}_{\text {DIE }}$ and PRON POSSESSIVE $+\mathrm{N}$ express the specific referentional connections and contain the information about the incidents of death of specific people: 
"But now I was seeing a natural death..." (A. Rice "Interview with the vampire", p. 29); "And as he moaned and prayed for death" (A. Rice "Interview with the vampire", p. 29); "Maybe she wants to die" (A. Rice "Prince Lestat", p. 112); "You will die, you know" (A. Rice "Interview with the vampire", p. 15); "...where we had planned the death" (A. Rice "Interview with the vampire", p. 11); "... responsible for his death..." (A. Rice "Interview with the vampire", p. 6); "...watch my death..." (A. Rice "Interview with the vampire", p. 13); "... tell you of her death..." (B. Stoker "Dracula", p. 188). It was noticed that personal pronouns, which have nonpersonal meanings in some situations, are not used in such contexts. The facts of life and death of specific people are represented with the help of the demonstrative pronoun with the meaning of close reference, according to the experience: "this is life and death" (about Mina) (B. Stoker "Dracula", p. 240); "This is death..." (about Claudia's mother) (A. Rice "Interview with the vampire", p. 54); "This was not death..." (about Rossi) (E. Kostova "The historian", p. 290).

With the help of collective nouns army, audience, family the scale of death is actualized, to which big groups of people are surrendered: "Death standing before the audience..." (A. Rice "Interview with the vampire", p. 119); "...entire family to death..." (J. Frost "First drop of crimson", p. 121).

\subsection{Actants of the sphere of UNEXISTENCE}

It should be noted that among ACTANTS there is the substantivized adjective Undead, which is peculiar to the sphere UNEXISTENCE. With the help of the definite article the ("He was the undead" (L. Hamilton "Guilty pleasures", p. 3); "Dracula had become one of the undead" (E. Kostova "The historian", p. 29)), a demonstrative pronoun this with the meaning of the close reference ("I was, in fact, beginning to shudder at the presence of this being, this UnDead (about Dracula)" (B. Stoker "Dracula", p. 171) and of the possessive determiners ("Even now, his (about Barlow) Undead are crawling over it" (S. King "Salem's lot", p. 244), appears the concretization of the notions of life and death in the sphere of UNEXISTENCE / UNDEAD. The inner form of the lexeme Undead 
testifies that it contains a feature, which combines the characteristics of alive and undead: "Denise to the hundreds of people, alive and undead" (J. Frost "First drop of crimson", p. 20).

The explication of the different (gender, social, and age) characteristics of people, usage of proper names, nouns with specific meaning, possessives and demonstratives for the description of the situation proves that the Gothic understanding of the world is directed at the concrete character, reality of LIFE, the possibility of its studying, gaining of some experience about different phenomena. DEATH is interpreted as inevitability, obscurity, uncertainty, and horror, which is proved with the usage of the lexemes pain, harshness, and fear. The sphere of UNEXISTENCE demonstrates the combination of features which are peculiar to both spheres LIFE and DEATH, which determine the particularity of their understanding in the Gothic worldview.

\section{Predicates of spheres of LIFE and DEATH}

\subsection{Predicates of the sphere of LIFE}

PREDICATES of the sphere of LIFE identify it as an action, event, process mostly with the help of verbs of the active voice. Depending on the belonging of the units to some particular lexico-semantic groups, one or another feature of LIFE is depicted.

Verbs of action, especially creative activity (make), gaining and alienation (bring, give, get, take), actualize the intensity and value of life ("... bring Turgut to life..." (E. Kostova "The historian", p. 96); "... be brought to life..." (E. Kostova "The historian", p. 259); "... brought me back to life..." (J. Frost "First drop of crimson", p. 206); "... give back your life..." (A. Rice "Interview with the vampire", p. 165); "...get the life..." (B. Stoker, "Dracula", p. 230); "... get to live forever..." (C. Clare "City of bones", p. 153); "...take my life..." (A. Rice "Interview with the vampire", p. 11); "... take a human life..." (J. Rollins "The blood gospel", p. 71); "... take its life..." (N. Roberts "Morrigan's cross", p. 64), its direction on the creative activity, building and 
not destroying of something ("... make your life..." (A. Rice "Prince Lestat", p. 62); "...make a new life..." (C. Clare "City of bones", p. 229).

With the help of the usage of verbs of speaking (ask, offer, talk, claim), mental activity (know, think, believe, remember, understand), denotation of physical perception (hear, see, taste), verbs of influence and of social and inter-personal relationship (love), verbs showing desire (want), the connection between life and a person's experience is set up. For example: "talks ... about her life" (C. Clare "City of bones", p. 19); "Life was all she could think ..." (N. Roberts "Morrigan's cross", p. 459); "... know about life..." (E. Kostova "The historian", p. 229); "He loves his life..." (N. Roberts "Morrigan's cross", p. 15); "Life is all I want ..." (B. Stoker "Dracula", p. 228); "... wanted to follow life..." (E. Kostova "The historian", p. 92); "... to taste life..." (P. Cast "Marked", p. 158); "...see a human life..." (A. Rice "Interview with the vampire", p. 46); "...heard life outside..." (J. Rollins "The blood gospel", p. 54); "...understand life..." (J. Rollins "The blood gospel", p. 130). But, there are some verbs, in the analyzed contexts, which depict the events, that occur without any visible doer: "Her life had become a very strange ride" ( $\mathrm{N}$. Roberts "Morrigan's cross", p. 52), "... changed my life..." (E. Kostova "The historian", p. 26), "...focus in my life has changed ..." (P. Cast "Marked", p. 4).

The usage of the verb be and of verbs with a full meaning (seem, keep, look, feel, sound, taste, smell) as components of the predicative structures $(\mathrm{V}+\mathrm{Adj}-$ be meaningless, seem dear, keep alive, etc.) ensures the multi-aspect characteristics of life and indicates such aspects, which are important for the comfortable existence of the person in the world ("I would be alive" (A. Rice "Prince Lestat", p. 12); "... keep you alive" (A. Rice "Interview with the vampire", p. 11): stability ("life was fixed" (A. Rice "Prince Lestat", p. 38), prosperity ("life was rich and good" (A. Rice "Interview with the vampire", p 37); "life was both luxurious and primitive" (A. Rice "Interview with the vampire", p. 4), value and necessity ("life seemed very dear" (S. King "Salem's lot", 
p. 177). Without all of these life loses its expediency ("life was meaningless" (A. Rice "Prince Lestat", p. 38).

\subsection{Predicates of the sphere of DEATH}

For the representation of the predicates of the sphere of DEATH most of the same verbs are used: the activity of creation, gaining and alienation - "... hesitate to bring death..." (A. Rice "Interview with the vampire", p. 54); "when I bring death" (A. Rice "Interview with the vampire", p. 30); "...make right the death..." (C. Clare "City of bones", p. 102); "... take death..." (N. Roberts "Morrigan's cross", p. 235); "... can give you death" (A. Rice "Interview with the vampire", p. 66); "Death... given back..." (B. Stoker "Dracula", p. 137). The actants of the described situations are mostly non-real creatures (as it was while describing the sphere LIFE), but monsters, vampires, who ruin life, take it away for continuing their own existence in the alien versus the human world: "when you had died, have become nosferatu..., and would for all time make more of those Un-Deads that so have filled us with horror... but if she lives on, UnDead, more and more they lose their blood and by her power over them they come to her, and so she draw their blood with that so wicked mouth" (B. Stoker "Dracula", p. 183).

The units with causative meaning appeared to be very effective (cause, allow, let): "... cause sudden death..." (A. Rice "Interview with the vampire", p. 34), "... allow the death..." (P. Cast "Marked", p. 110); "... let you die..." (A. Rice "Interview with the vampire", p. 15). They intensify the contrast between the creative power of men, dynamics, and productivity of life and passive state and probability or unexpectedness of actions, influence, changes of circumstances, which are connected with death (let be removed by death). For example, we can compare the context about life as an act of creation and continuation of generations (make life), and the context, where it is mentioned, only about the willingness, impulse for acting, or another call for action (let be removed by death): "there are good women... to make life happy ... for the 
children that are to be" (B. Stoker "Dracula", p. 157); "Let any obstructing cause, no matter what, be removed in any way, even by death" (B. Stoker "Dracula", p. 47).

As for the usage of verbs of speaking (talk, speak), mental activity (know, think), denotations of physical perception (hear, see, taste), verbs of influence (cause, allow, let), and also social and inter-personal relationship (love), verbs showing wishes (wish, want), they are also possible.

At the same time, it should be noted, that there are some peculiarities of the representation of the sphere of DEATH with the help of such verbs.

The connection of the notion of 'death' with the rational experience of the person but not with perceptual is prevailing ("... think of death ..." (B. Stoker "Dracula", p. 248); "...can think ... to death" (N. Roberts "Morrigan's cross", p. 505); "... think about death..." (J. Frost "First drop of crimson", p. 20); "...know more about death ..." (J. Frost "First drop of crimson", p. 112).

Only the fact of the natural loss of life by a human is perceived with the help of senses ("...seeing a natural death ..." (A. Rice "Interview with the vampire", p. 29); "... can see death..." (A. Rice "Interview with the vampire", p. 46), and everything that occurs after death is beyond human perceptions ("... talk of mysterious death" (A. Rice "Interview with the vampire", p. 27). Information about death ("..felt the pain of death ..." (E. Kostova "The historian", p. 310) does not have its proper understanding, which is confirmed by the usage of comparative-approximate constructions ("tastes... like death..." (B. Stoker "Dracula", p. 63) and emotionally expressive phrases ("heard the death watch" (B. Stoker "Dracula", p. 236); "if I heard this moment the flapping of the wings of the angel of death" (B. Stoker "Dracula", p. 134), in which metaphorspersonifications ensure the concretization of the abstract idea of death, based not on suppositions, but on facts. 
The motive of the mysteriousness and obscurity of death becomes more clear as a result of using the construction $\mathrm{V}_{\text {COPULA }}+\mathrm{ADJ}$, especially if the copula verb is represented by the lexeme seem "to give the effect of being; to be judged to be" (Cambridge Dictionary Online): "... death had seemed peaceful..." (J. Rollins "The blood gospel", p. 173).

\subsection{Predicates of the sphere of UNEXISTENCE / UNDEAD}

The predicates of the sphere of UNEXISTENCE / UNDEAD are represented with the help of verbs, in the meaning of which are the semes 'destruction', 'demolition', 'consumption' ("the Count had sucked her blood" (about the vampire) (B. Stoker "Dracula", p. 251), and by verbs showing desire ("... he wished her death <... want her death..." (A. Rice "Interview with the vampire", p. 163). On the one hand, the associative connection with active functioning makes the sphere of UNEXISTENCE / UNDEAD close to the sphere of LIFE. On the other hand, the destructive character of the actions, peculiar to this sphere, makes it similar to the sphere of DEATH. The usage of verbs showing desire expresses both the explication of real wishes, emotions (want), and unreal (wish). The predicates that are used to depict the sphere of DEATH are combined into a system, which meaningful syncretism is intensified by the usage of constructions with the verb become "to start to be" (Cambridge Dictionary Online), with the help of which the possibility of changing, creating, appearing, and changing into another state is actualized: "... Dracula had become one of the undead, in life - in the course of history" (E. Kostova "The historian", p. 29); "...become forever undead" (E. Kostova, "The historian", p. 139).

To sum it up, the predicates represent the sphere of LIFE with the help of the group of verbs make, bring, give, get, take, etc., which determine its creative activity and direction to the creation of something new, and the verbs ask, offer, see, taste, understand, want, etc., show the experience of the human being, which was continuing during the entire period of existence. For the sphere of DEATH the most actual were the same verbs, but they refer not to the perceptive (think), but to the rational, real 
experience. The connection between the spheres of LIFE and DEATH is represented in the sphere of UNEXISTENCE / UNDEAD, which combines the activity of the first and the destructive power of the second.

The predicates of the spheres of LIFE and DEATH are represented by verbs of motion, perception and rational activity, and also with verbs of existing and changes of state. Despite the fact that the predicates of the antonymic shares correlate with each other by using the same lexico-semantic classes, they are not of the same effectiveness for verbalization of the cognitive features of the concepts under analysis. The verbs of motion, which are connected with the sphere of LIFE, show the relation of this sphere to constructive activity, to instructions of making something useful and new, and verbs, which correlate with the sphere of DEATH, on the contrary, actualize the ideas of demolishing and destruction.

The predicates of the sphere of LIFE show the importance of perception, while the predicates of the sphere of DEATH indicate the limitedness of the perceptive experience of the person and the necessity of the rational learning of death as a phenomenon. Constructions, which include the copulative verb and the adjective, make accent on the variety, brightness, multiple character and differences of life, and the mystery and obscurity of death for all humanity. The intermediate sphere of UNEXISTENCE / UNDEAD, which combines the characteristics of both spheres of LIFE and DEATH, is also represented with the help of predicates. The mediate character of this sphere is underlined with the help of the means of explication of the ideas of changeability, the transition from one state to another.

\section{Attributes of the spheres of LIFE and DEATH}

\subsection{Attributes of the sphere of LIFE}

Attributes of the LIFE and DEATH spheres actualize the essential and inalienable characteristics of conceptualized opposition with the help of adjectives, which correlate with different classes. 
The qualitative adjectives prevail in the representations of the sphere of LIFE: happy, precious, sweet, and long ("being eternally happy $<\ldots>$ beginning the great adventure of our lives" (A. Rice "Prince Lestat", p. 79); "his life, which is so precious to me" (A. Rice "Interview with the vampire", p. 140). They demonstrate direct characteristics of the objects and phenomena, which can be distinguished in different degrees. The verbalizations of life are represented by meanings, which show its value, the satisfaction and delight, which people receive while being alive.

Relative adjectives show the characteristics of life according to such attitudes: to the person ("taking human life even when you have no need" (A. Rice "Interview with the vampire", p. 45), to time ("our eternal life was useless to us if we did not see the beauty around us" (A. Rice "Interview with the vampire", p. 56); "early life" (C. Clare "City of bones", p. 19), to an abstract notion ("exotic and sophisticated life" (A. Rice "Interview with the vampire", p. 111).

The positive attitude to life is represented very brightly with the help of such forms and constructions:

- the comparative and the superlative degrees of comparison of adjectives, which ensure the verbalization of the intensified representation of the positive characteristics, value, etc. ("... a happier family life ..." (R. Mead "Vampire academy", p. 143); "... life at its sweetest and most generous" (N. Roberts "Morrigan's cross", p. 406);

- combinations of adjectives with the intensifier very (very long) or repetitions (long long), which emphasize the big or enormous degree of display of the positive feature ("Life... very long ..." (C. Clare "City of bones", p. 153); "... life seemed very dear" (S. King "Salem's lot", p. 177); "...what might be a very long life ..." (J. Frost "First drop of crimson", p. 126); "long, long life" (S. King "Salem's lot", p. 196); 
- coordinative constructions, in the structure of which the conjunction 'and' combines the adjectives with incoherent positive and corresponding meanings ("life was rich and good" (A. Rice "Interview with the vampire", p. 37); "life... both exquisite and good" (A. Rice "Interview with the vampire", p. 174).

We consider that these means and methods are used to intensify and increase the significance of the understanding of the phenomenon of life.

\subsection{Attributes of the sphere of DEATH}

The characteristics of the sphere of DEATH are determined by the usage of qualitative adjectives (black, white, untimely, mysterious, quick), which characterize death as 'untimely', 'mysterious', and 'quick' ("mysterious death" (E. Kostova "The historian", p. 28); "quick death" (J. Rollins "The blood gospel", p. 12). Relative adjectives (unbearable, deliberate) show the 'unbearable character' and 'unacceptability' of death for the human ("untimely death" (J. Frost "First drop of crimson", p. 132); "dying was unbearable" (A. Rice "Prince Lestat", p. 32); "death had been deliberate" (A. Rice "Prince Lestat", p. 6)). Obscurity of this phenomenon is realized in the opposition via representing death in different colors ("...black ... death" (A. Rice "Interview with the vampire", p. 175) vs "The poor dear grew white as death..." (B. Stoker "Dracula", p. 248) and coordinative constructions ("death would be neither quick nor painless..." (J. Rollins "The blood gospel", p. 95).

The polarity of the value seems very important. On the one hand, the positive attitude to life if actual ("good life" (A. Rice "Interview with the vampire", p. 3); "positive life" (B. Stoker "Dracula", p. 199), but, on the other hand, it is perceived negatively because of all the obstacles, difficulties, etc., which the person should overcome during the lifetime ("unpleasant life" (E. Kostova "The historian", p. 82); "awful life" (J. Frost "First drop of crimson", p. 179); "miserable life" (R. Mead "Vampire academy", p. 178); "horrible life" (R. Mead "Vampire academy", p. 170); "life seems deadly" (A. 
Rice "Prince Lestat", p. 21). Death, also, is represented both positively and negatively ("great death" (J. Rollins "The blood gospel", p. 24) vs "grisly death" (R. Mead "Vampire academy", p. 192).

\subsection{Attributes of the sphere of UNEXISTENCE / UNDEAD}

Such ambiguity of the interpretation of life and death shows the fact that Gothic linguoculture attempts to combine these notions, but not separate them. The middle part between them is the sphere of UNEXISTENCE / UNDEAD. The appeal to this sphere is realized, in some cases, with the help of adjectives with positive meaning: "young as UnDead" (B. Stoker "Dracula", p. 173); "the UnDead are strong" (B. Stoker "Dracula", p. 173); "his so beloved was, after all, an UnDead" (B. Stoker "Dracula", p. 172); "this great UnDead" (B. Stoker "Dracula", p. 173); "the quick Undead" (B. Stoker "Dracula", p. 248); "active Undead" (B. Stoker "Dracula", p. 203); "The Count stood up, and said, with a sweet courtesy" (B. Stoker "Dracula", p. 40).

But, the world of the undead, as far as death is concerned, remains incomprehensible and unacceptable for people. The vampires (UnDead), who travel between life and death, destroy creatures ("The vampire lived indefinitely, feasting on the blood of mortals and there by converting them to his own undead state" (E. Kostova "The historian", p. 29); "I absorb power from the undead blood" (J. Frost "First drop of crimson", p. 163). They are characterized very negatively ("the whole awful creature ... lay like a filthy leech, exhausted with his repletion" (E. Kostova "The historian", p. 42). And the features, which correlate with the sphere of life in their representation, are overexaggerated, unnatural and not stable ("the voice of the Count calling in his harsh, metallic whisper" (B. Stoker "Dracula", p. 37); "The cheeks were fuller, and the white skin seemed ruby-red... The mouth was redder than ever" (B. Stoker "Dracula", p. 42); "the white hair and moustache were changed to dark iron-grey" (B. Stoker "Dracula", p. 42) and that is why irrelevant for the world of people. 
The characteristics of positiveness and duration of the sphere of LIFE, which are exaggerated and are represented with the help of comparative and superlative degrees of comparison of qualitative adjectives, their usage in the structure of coordinative constructions and also of relative adjectives represent the importance of life for people. The characteristics of the sphere of DEATH show its negative, mysterious and short features with the help of correlative constructions and the denotation of color. The sphere of UNEXISTENCE / UNDEAD combines features, which are inherent in both spheres, as it is defined as a state, which represents the edge between life and death, and is characterized by changes.

\section{Quantifiers of the spheres of LIFE and DEATH}

The quantifiers of the spheres of LIFE and DEATH are represented with the designation of the quantitative relations. The verbalizers are not productive and show the connection 'the whole - the part', where life and death are represented as the whole ("part of life" (R. Mead "Vampire academy", p. 48); "a part of death" (B. Stoker "Dracula", p. 190). The usage of the key nominations in the plural form ("many in my lifetimes" ( $\mathrm{N}$. Roberts "Morrigan's cross", p. 62); "every night of our lives" (A. Rice "Interview with the vampire", p. 78); "four deaths" (S. King "Salem's lot", p. 187), and also in the connection with the adjectives single "only one; considered separate from other things" (Cambridge Dictionary Online) and each "every thing, person, etc., in a group of two or more, considered separately" ("before ever taking a single life" (J. Rollins "The blood gospel", p. 165), "each death was recorded in giant electronic computers" (A. Rice "Prince Lestat", p. 7) demonstrates the reduction of the abstract character of the conceptualized notions.

\subsection{Quantifiers of the sphere of UNEXISTENCE / UNDEAD}

Unlike the singular character of the notions of 'life' and 'death', the verbalization of the sphere of UNEXISTENCE represents the opposite tendency to plurality. This is confirmed by the usage of the lexemes all "every individual of the given class" (The Oxford English Dictionary) ("And this was the condition of existence among all the Undead" 
(A. Rice "Prince Lestat", p. 228) and the determinative one, which does not show any feature of the object or phenomenon (which is represented by the noun), but diplays the quantity - "one of the many, from the whole class of similar ones" ("that Dracula had become one of the undead" (E. Kostova "The historian", p. 29).

It should be noted that among the quantifier of the sphere of UNEXISTENCE there are also some of the intensified indications of plurality - far more, the largest number, which determine the 'great amount of something' - "surrounded by far more undead people than living ones" (J. Frost "First drop of crimson", p. 20); "Their best hope of finding Nathanial was to expose Denise to the largest number of undead persons and their property at a time" (J. Frost "First drop of crimson", p. 26).

So, the quantifiers of the spheres of LIFE and DEATH represent these concepts as something 'general and individualized', while the sphere of UNEXISTENCE / UNDEAD tends to plurality and is contrasted to them. At the same time UNEXISTENCE is combined with these spheres, as with the help of quantifiers it is represented, also, as 'something separate from the group, class of objects'.

\section{Spatial characteristics of the spheres of LIFE and DEATH}

For the spheres of LIFE and DEATH both horizontal ("he [human being] had enjoyed this ride from his cottage to his family home, through the fields, or along" (N. Roberts "Morrigan's cross", p. 29) and vertical ("He [human being] crawled and clawed his way up the cliff" (N. Roberts "Morrigan's cross", p. 12) parameters were significantly important.

\subsection{Spatial characteristics of the sphere of LIFE}

The sphere of LIFE is represented by such aspects:

- 'substantial' - the ground, the way ("It was I who subverted the path his life might have taken" (A. Rice "Prince Lestat", p. 259); topographical notions ("we [human 
beings] swept round the base of a hill and opened up the lofty, snow-covered peak of a mountain" (B. Stoker "Dracula", p. 7);

- 'unlocked' - outside ("life outside" (J. Rollins "The blood gospel", p. 54);

- 'extraverted' - populated, saturated (".. life in New Orleans..." (A. Rice "Interview with the vampire", p. 24); "... early life in the United States..." (E. Kostova "The historian", p. 2);

- 'sheltered, secure' - "sheltered life" (N. Roberts "Morrigan's cross", p. 364);

- only in some cases 'closed, limited' ("monastic life" (E. Kostova "The historian", p. 229), that corresponds, mostly, to the emotional and psychological state of people, but not the physical space.

\subsection{Spatial characteristics of the sphere of DEATH}

Among the spatial characteristics of the sphere DEATH there are horizontal ("staring into the face of death $<\ldots>$ having only one path to follow" (A. Rice "Interview with the vampire", p. 24) and vertical ("Eleazar pictured blood ... seeping toward the mountain's core <..> Those deaths marked the final dark" (J. Rollins "The blood gospel", p. 4).

The horizontal line is connected with the position of the dead body and substantional aspect (coffin - "to place them [vampires] into the shapely wooden coffins" (A. Rice "Prince Lestat", p. 348); grave - "I lie in my grave" (A. Rice "Prince Lestat", p. 164), and the vertical line is connected with the existential aspect (heaven - "Even the stars of Heaven hid behind clouds" (J. Rollins "The blood gospel", p. 82); air - "The image of Mike Ryerson hanging in the dark air" (S. King "Salem's lot", p. 143).

The space of DEATH is represented by such aspects: 
- 'closed' - a small building ("a house of death" (B. Stoker "Dracula", p. 123); "death in the small house" (A. Rice "Interview with the vampire", p. 59); limited territory ("land of death" (E. Kostova "The historian", p. 164); "garden of death" (E. Kostova "The historian", p. 51);

- 'introverted' - empty, deserted ("death in the desert" (J. Rollins "The blood gospel", p. 100); "death at ... dark wood" (A. Rice "Interview with the vampire", p. 119);

- 'unprotected, dangerous' - "I am shut up here [in Dracula's castle], a veritable prisoner, but without that protection of the law" (B. Stoker "Dracula", p. 36); "after Randy's death, every shadow was something sinister waiting to pounce on her" (J. Frost "First drop of crimson", p. 2).

The combination of the features of reticence and emptiness is explained by the influence of stable archaic understandings about death as about the possibility to get free, to get rid of limitations. The space, in which the body of the dead is put, becomes wider and the soul leaves it, uniting the human with the Universe.

\subsection{Spatial characteristics of the sphere of UNEXISTENCE / UNDEAD}

The special characteristics of the sphere of UNEXISTENCE / UNDEAD syncretically unite the special characteristics of the spheres of LIFE and DEATH:

- horizontal and vertical - "...I saw the whole man [UnDead] slowly emerge from the window and begin to crawl down the castle wall over the dreadful abyss" (B. Stoker "Dracula", p. 29); "He moved downwards" (B. Stoker "Dracula", p. 28); "I am closing the tomb so that the UnDead may not enter" (B. Stoker "Dracula", p. 179);

- locked and unlocked - "He [UnDead] is confined within the limitations of his earthly envelope" (B. Stoker "Dracula", p. 249) and "He [UnDead] can, when once he find his way, come out from anything or into anything" (B. Stoker "Dracula", p. 204); 
- extraverted and introverted - "graves that are inhabit" (B. Stoker "Dracula", p. 302) and "the tomb [of the UnDead] ... hidden from the sight of any one approaching" (B. Stoker "Dracula", p. 179);

- sheltered, but dangerous at the same time - "The place felt close and dangerous over my [vampire's] head" (A. Rice "Prince Lestat", p. 97).

So, the spheres of LIFE and DEATH are actualized with the help of horizontal and vertical characteristics. The sphere of LIFE is characterized by such features as substantional, extraverted, open, and safe. The sphere of DEATH is represented as locked, introverted, and dangerous. The sphere of UNEXISTENCE / UNDEAD combines the features of both spheres that affirm its syncretism and integrity in the representation of the Universe in the Gothic worldview.

\section{The time of the spheres of LIFE and DEATH}

10.1 The time of the sphere of LIFE

The time of the sphere of LIFE is represented with the help of such means:

- nouns, which determine the prolonged period of time - era, decade, century, year, etc. ("an era of your life" (A. Rice "Interview with the vampire", p. 157); "an earlier era of my life" (E. Kostova "The historian", p. 67); "decades of life" (E. Kostova "The historian", p. 289)) and are used together with quantitative numerals ("more than two centuries" (D. Reynolds "Raphael", p. 19); "several hundred years" (D. Reynolds "Raphael", p. 53);

- nouns, which determine the beginning, the duration, or the end of an action beginning, continuation, end, etc. ("...beginning a new life..." (P. Cast "Marked", 
p. 26); "... continuation of life..." (E. Kostova "The historian", p. 290); "... end my own life..." (C. Clare "City of bones", p. 226);

- units, which determine the repetition, cyclic character of an action or phenomenon - circle, third, next ("... life is a circle ..." (P. Cast "Marked", p. 80); "... third of my life..." (C. Clare "City of bones", p. 150) and quantitative ("next twenty years of his life..." (S. King "Salem's lot", p. 147).

\subsection{Time of the sphere of DEATH}

The sphere of DEATH is represented with the help of means, which actualize the opposite features:

- nouns, which determine very short periods of time - moment, etc. ("at the moment of death" (S. King "Salem's lot", p. 108);

- units, which determine the end or the stop of an action or process - end, point, etc. ("end with death" (E. Kostova "The historian", p. 289); "to the point of death" (A. Rice "Interview with the vampire", p. 7); "final death" (A. Rice "Interview with the vampire", p. 28);

- adverbs, which contain in their lexical meaning the seme 'the starting point' and are used to determine the edge with the further actions - after, since, upon ("... after his death..." (E. Kostova "The historian", p. 294); "... since the night of King's death..." (N. Roberts "Morrigan's cross", p. 433); "... upon his death..." (E. Kostova "The historian", p. 245).

Significant is the fact that via attributives the appeal to the time characteristics of life and death is frequently implemented. Gothic understanding of the world tends to the ambiguous, dichotomic interpretation of the connections of life and death with time 
("... death would be neither quick nor painless..." (J. Rollins "The blood gospel", p. 95).

Life and death are simultaneously understood as quick and passing ("short life" (J. Frost "First drop of crimson", p. 189) vs. "millennia-long life" (J. Rollins "The blood gospel", p. 239); "... a long dead emotion" (D. Reynolds "Raphael", p. 99) vs. "...each in her full sleep of death for a short moment ..." (B. Stoker "Dracula", p. 304); those, which are connected with the past and the future ("previous life" (E. Kostova "The historian", p. 13) vs. "next ... life" (S. King "Salem's lot", p.147); "old life" (J. Rollins "The blood gospel", p. 83) vs "new life" (P. Cast " Marked", p. 117); "old death" (J. Rollins "The blood gospel", p. 165) vs. "early death" (J. Frost "First drop of crimson", p. 191); "untimely death" (M. Kruz "Blue bloods", p. 28).

\subsection{Time of the sphere of UNEXISTENCE / UNDEAD}

Time characteristics of the sphere of UNEXISTENCE / UNDEAD are actualized with the help of such lexical means:

- adverbs, which are used to define the indeterminable close time (now) and eternity (forever) - "the most blessed of all, when this now UnDead be made to rest as true dead" (B. Stoker "Dracula", p. 183); "if he will receive the third evil benediction soon and become forever undead" (E. Kostova "The historian", p. 139);

- adverbs, which show the final and complete change of action, features of an object or phenomenon - already ("a body, that is at risk for becoming undead, or is already undead" (E. Kostova "The historian", p. 257).

\section{Conclusion}

In conclusion we may say that the time features of the sphere of LIFE show its interpretation in Gothic linguoculture as of something 'very long', 'durable', 'unending', and 'cyclic'. The opposite cognitive features correlate with the sphere of DEATH - 'short 
duration', 'instantaneity', 'irreversibility'. The sphere of UNEXISTENCE / UNDEAD syncretically combines the cognitive features of the spheres of LIFE and DEATH, which modify in order to recreate the 'indetermination' of this sphere, its 'moderation': 'duration' and 'unending' of LIFE is shown with the features 'uncertainty' and 'obscurity'. In addition, such a feature of the sphere of DEATH as 'ending' transforms into 'irrevocability of changes, which occur'.

The actants of the sphere of LIFE are represented with the help of definite nouns, which show the dimension 'human being' from different points of view, personal, possessive, and demonstrative pronouns, establish relations of 'proximity - distance' and also 'reality - non-reality' of the conceptual phenomenon in the consciousness of speakers.

The representatives of the concept of DEATH are, mainly, abstract nouns with negative meaning, which indicate the fear and anticipation of death as of something unknown and obscure, and also nouns, which are used to represent unalive or fictional creatures. For the sphere of UNEXISTENCE the most common is the usage of the substantivized adjective Undead, which shows the connection between both spheres, as far as it represents unalive but active creatures.

The predicates, which characterize the concepts of LIFE and DEATH, define them as two opposite phenomena, revealing the real character of LIFE and the mysterious one of DEATH. The usage of the same verbalizers for both concepts shows their connection and the possibility to complete each other.

The attributes of the spheres of LIFE and DEATH, which are used to determine their duration, have positive results in determining LIFE ('beautiful', 'colorful', 'long') and DEATH as its opposition - negatively ('dreadful', 'dark', 'short'). The intermediate sphere of UNEXISTENCE is represented as 'changeable' and 'unknown', and is represented 
with the help of verbs, which show desire, which indicate both the real plan of the situation (want) and the unreal, the desire to change the state of things (wish).

The quantificators and the characteristics of time and place of the spheres of LIFE and DEATH underline the cyclical character of life, the possibility of its division into different stages, one of which appears to be death. The special characteristic indicates the sphere of LIFE as an open secure space, and DEATH is represented as a closed, limited space full of dangers. The sphere of UNEXISTENCE / UNDEAD is somewhere in-between these two worlds and combines the features, which are peculiar to both these spheres, which is represented in its definition as 'syncretic', 'changeable', and 'ambiguous'.

\section{References}

Boldyrev, N.N. (2001). Cognitive semantics: A course of lectures on English philology. Tambov: TamGU Publishing. / Boldyrev N.N. Kognitivnaya semantika: Kurs lektsij po anglijskoj filologii. Tambov: Izdatel'stvo TamGU. / Болдырев Н.Н. Когнитивная семантика: Курс лекций по английской филологии. Тамбов: Издательство ТамГУ. Burke, E. (1979). The philosophical studies about the origin of our ideas of the sublime and beautiful / Byork E. Filosofskoye issledovaniye o proiskhozhdenii nashikh idej vozvyshennogo $i$ prekrasnogo / Бёрк Э. Философское исследование о происхождении наших идей возвышенного и прекрасного. Available at: http://scibook.net/estetika-uchebnik/filosofskoe-issledovanie-proishojdeniinashih.html

Cambridge Dictionary Online. Available at: http://dictionary.cambridge.org

Cast, P.S. (2007). Marked. New York: St. Martin's Griffin.

Clare, C. (2015). City of bones. New York: Walker Books.

Davydyuk, Yu. \& Panasenko, N. (2016). Figuring the male and female: fire and water in Bradbury's (science) fiction. In Lege artis. Language yesterday, today, tomorrow. The journal of university of SS Cyril and Methodius in Trnava. Warsaw: De Gruyter Open, I (1), p. 4-74. DOI: 10.1515/lart-2016-0001. 
Dijk, T.A. van (1989). The Language. The Cognition. The Communication. Moscow: Progress. / Dejk T.A. van. Yazyk. Poznaniye. Kommunikatsiya. Moskva: Progress. I Дейк Т.А. ван. Язык. Познание. Коммуникация. Москва: Прогресс.

Devison, C. (2009). History of the Gothic. Gothic literature 1764-1824. Cardiff: University of Wales Press.

Ermolayeva, E.N. (2005). The concept CONFLICT and its objectivization in the lexicosemantic sphere of the modern English language. Thesis for the candidate degree in philology. Speciality 10.02.04 - Germanic languages. Kemerovo: Kemerovo National University. / Ermolayeva E.N. Kontsept KONFLIKT i yego obyektivatsiya v leksikosemanticheskom prostranstve sovremennogo anglijskogo yazyka. Dissertatsiya na soiskaniye uchyonoj stepeni kandidata filologicheskikh nauk. Spetsial'nost' 10.02.04 germanskiye yazyki. Kemerovo: Kemerovskij natsionalnyj universitet. / Ермолаева E.H. Кониепт CONFLICT и его объективаџия в лексико-семантическом пространстве современного английского языка. Диссертация на соискание ученой степени кандидата филологических наук. Специальность $10.02 .04-$ германские языки. Кемерово: Кемеровский национальный университет.

Fillmore, Ch.J. (1985). Frames and the semantics of understanding. In Quaderni di semántica, 6, p. 222-254.

Frost, J. (2010). First drop of crimson. New York: Avon.

Hajduchenko, L.V. (2009). The concept POWER in the modern German linguoculture. Synopsis for thesis for the candidate degree in philology. Speciality $10.02 .04-$ Germanic languages. Kyiv: Taras Shevchenko National University of Kyiv. I Hayduchenko L.V. Kontsept VLADA v suchasnij nimets'kij linhvokul'turi. Avtoreferat dysertatsiyi na zdobuttya vchenoho stupenya kandydata filolohichnykh nauk. Spetsial'nist' 10.02.04 - hermans'ki movy. Kyyiv: Kyyivs'kyj natsional'nyj universytet imeni T. Shevchenka. / Гайдученко Л.В. Кониепт ВЛАДА в сучасній німецькій лінгвокультурі. Автореферат дисертації на здобуття вченого ступеня кандидата філологічних наук. Спеціальність 10.02.04 - германські мови. Київ: Київський національний університет імені Тараса Шевченка.

Hamilton, L. (2002). Guilty pleasures. New York: Jove. 
Horner, A. (1998). Moving pictures: Family portraits, Gothic anxieties and Daphne du Maurier's Rebecca. In Fictions of unease: The Gothic from Otranto to The X-files. Smith, A., Mason, D. \& Hughes, W. (eds.). Bath: Sulis Press, p. 170-182.

Ihina, Z. (2018). Intermediality and polymorphism of narratives in the Gothic tradition. In Lege artis. Language yesterday, today, tomorrow. The journal of University of SS Cyril and Methodius in Trnava. Warsaw: De Gruyter Open, 2018, III (1), June 2018, p. 80-123. DOI: 10.2478/lart-2018-0003

Karasik, V.I. (2004). Language circle: Personality, concepts, discourse. Moscow: Gnozis. / Karasik V.I. Yazykovoj krug: Lichnost', kontsepty, diskurs. Moskva: Gnozis. / Карасик В.И. Языковой круг: Личность, концепты, дискурс. Москва: Гнозис.

King, S. (2011). Salem's lot. New York: Anchor.

Kostova, E. (2005). The historian. New York: Time Warner Books.

Koval', O.A. (2010). The concept "Lack of words" in English and Russian linguoculture. Thesis for the candidate degree in philology. Speciality 10.02.04 Germanic languages. Moscow: Moscow Region State University. / Koval' O.A. Kontsept "NEDOSKAZANNOST" v anglijskoj i russkoj lingvokul'ture. Dissertatsiya na soiskaniye uchyonoj stepeni kandidata filologicheskikh nauk. Spetsial'nost' 10.02 .04 germanskiye yazyki. Moskva: Moskovskij gosudarstvennyj oblastnoj universitet. I Коваль О.А. Конщепт "НЕДОСКАЗАННОСТЬ" в английской и русской лингвокультуре. Диссертация на соискание ученой степени кандидата филологических наук. Специальность 10.02.04 - германские языки. Москва: Московский государственный областной университет.

Kövecses, Z. (2015). Where metaphors come from: Reconsidering context in metaphor. Oxford: Oxford University Press.

Kruz, M. (2010). Blue bloods. London: Atom.

Lakoff, G. \& Johnson, M. (1980). Metaphors we live by. Chicago: The University of Chicago Press.

Langacker, R.W. (1990). Concept, image, and symbol: The cognitive basis of grammar. Berlin-New York: Mouton de Gruyter. 
Lipina, E.A. (2008). The realization of the linguocultural concept "TIME OF WAR / KRIEGZEIT" in the idiolects of K.M. Simonov and E.M. Remarque (based on the texts of the war novels). Synopsis for thesis for the candidate degree in philology. Speciality 10.02.20 - comparative-historical, typological, and contrastive linguistics. Tyumen': Tyumen' State University. I Lipina E.A. Realizatsiya lingvokul'turnogo kontsepta "VREMYA VOYENNOYE / KRIEGZEIT" v idiolektakh K.M. Simonova i E.M. Remarka (na materiale tekstov voyennoj prozy). Avtoreferat dissertatsii na soiskaniye uchyonoj stepeni kandidata filologicheskikh nauk. Spetsial'nost' 10.02.20 - sravnitel'noistoricheskoye, tipologicheskoye i sopostavitel'noye yazykoznaniye. Tyumen': Tyumenskij gosudarstvennyj universitet. / Липина Е.А. Реализация лингвокультурного концепта "ВРЕМЯ ВОЕНHOE / KRIEGZEIT" в идиолектах К.М. Симонова и Э.М. Ремарка (на материале текстов военной прозы). Автореферат диссертации на соискание ученой степени кандидата филологических наук. Специальность 10.02.20 - сравнительно-историческое, типологическое и сопоставительное языкознание. Тюмень: Тюменский государственный университет.

Lovecraft, H.P. (2009). Supernatural horror in literature. Available at: http://www.hplovecraft.com/writings/texts/essays/shil.aspx

Manerko, L. (2016). Towards understanding of conceptualization in cognitive terminology. In Lege artis. Language yesterday, today, tomorrow. The journal of University of SS Cyril and Methodius in Trnava. Warsaw: De Gruyter Open, I (2), p. 129-170. DOI: 10.1515//lart-2016-0012

Mead, R. (2007). Vampire academy. New York: Penguin Books.

Merriam-Webster Dictionary Online. Available at: https://www.merriam-webster.com Minsky, M. (1988). The wit and logic of the cognitive unconscious. In Advances in the foreign linguistics. Cognitive aspects of the language, 23, p. 281-310. / Minskij M. Ostroumiye i logika kognitivnogo bessoznatel'nogo. In Novoe $v$ zarubezhnoj lingvistike. Kognitivnyy aspekt yazyka, 23, s. 281-310. / Минский М. Остроумие и логика когнитивного бессознательного. In Новое в зарубежной лингвистике. Когнитивный аспект языка, 23, с. 281-310. 
Morris, D.B. (2004). Gothic sublimity. In Gothic. Critical concepts in literary and cultural studies. Botting, F. \& Townshend, D. (eds.). London-New York: Routledge, Taylor \& Francis Group, p. 50-68.

Oxford Living Dictionaries Online. Available at: https://en.oxforddictionaries.com

Panasenko, N. (2012). Linguistic markers of emotional concept LOVE in literary texts. In US-China foreign language, 10 (4), p. 1067-1084.

Pikhtovnikova, L.S. \& Honcharuk, O.M. (2010). Linguocognitive aspect of the investigation of the English fable. In Bulletin of the Kharkiv National University of V.N. Karazin, 62, p. 18-26. / Pikhtovnikova L.S. \& Honcharuk O.M. Linhvokohnityvnyj aspekt doslidzhennya anhlomovnoyi prozovoyi bajky. In Visnyk Kharkivs'koho natsional'noho universytetu im. V.N. Karazina, 62, s. 18-26. I Піхтовнікова Л.С., Гончарук О.М. Лінгвокогнітивний аспект дослідження англомовної прозової байки. In Вісник Харківського національного університету ім. В.Н. Каразіна, 62, с. 18-26.

Popova, Z.D. \& Sternin, I.A. (2007). Cognitive linguistics. Moscow: AST: "VostokZapad". / Popova Z.D. \& Sternin I.A. Kognitivnaya lingvistika. Moskva: AST "VostokZapad". / Попова З.Д., Стернин И.А. Когнитивная лингвистика. Москва: АСТ: "Восток-Запад".

Prihodko, A.I. (2014). Frame as a type of the lexical concept. In Topical issues of philology and pedagogical linguistics, 16, p. 110-113.

Prihodko, A. (2015). Concepts "Life" and "Death" in the modern novels about vampires. In Science and education a new dimension. Philology. Budapest, III (12), p. 13-15.

Prihodko, A.I. (2016). Cognitive-communicative organization of the evaluative frame. In Lege artis. Language yesterday, today, tomorrow. The journal of University of SS Cyril and Methodius in Trnava. Warsaw: De Gruyter Open, I (1), p. 275-308 DOI: 10.1515/lart-2016-0006

Prihodko, A.I. (2017). Concept and frame: Ways of solution of the problem. In Коллективная монография. Concepts and contrasts. Odessa: Hel'vetika Publishing House, p. 47-53. / Prihodko A.I. Kontsept i frejm: puti resheniya problem. In 
Kollektivnaya monografiya: Kontsepty $i$ kontrasty. Odessa: Izdatel'skij dom "Hel'vetika", s. 47-53. / Приходько А.И. Концепт и фрейм: пути решения проблемы. In Коллективная монография: Концепты и контрасты. Одесса: Издательский дом "Гельветика", с. 47-53.

Prykhodchenko, O. (2018). The role of structural metaphor in the representation of the concepts LIFE - DEATH in the Gothic worldview. In Topical issues of Romanic and Germanic philology and applied linguistics: Scientific journal, I (15), p. 281-284. I Prykhodchenko O. Rol' strukturnoyi metafory v reprezentatsiyi kontseptiv ZHYTTYA - SMERT' v hotychnij kartyni svitu. In Aktual'ni problemy romano-hermans'koyi filolohiyi ta prykladnoyi linhvistyky: naukovyj zhurnal, I (15), s. 281-284. I Приходченко О. Роль структурної метафори в репрезентації концептів ЖИТТЯ - СМЕРТЬ в готичній картині світу. In Актуальні проблеми романо-германської філологї̈ та прикладної лінгвістики: науковий журнал, I (15), с. 281-284.

Punter, D. (1996). The literature of terror: A history of Gothic fiction from 1765 to the present day. London: Longman.

Punter, D. (2004). The Gothic. Blackwell guides to literature. Oxford: WileyBlackwell.

Reynolds, D.B. (2013). Raphael. Memphis: ImaJinn Books.

Rice, A. (2012). Interview with the vampire. Saint Petersburg: Sphere.

Rice, A. (2015). Prince Lestat. Saint Petersburg: Sphere.

Roberts, N. (2007). Morrigan's cross. New York: Jove.

Rollins, J. (2013). The blood gospel. New York: Harper.

Selivanova, E.A. (2000). Cognitive onomasiology. Kyiv: Ukrainian Phytosociological Centre Publishing House. / Selivanova E.A. Kognitivnaya onomasiologiya. Kiev: Izdatel'stvo ukrainskogo fitosotsiologicheskogo tsentra. / Селиванова Е.А. Когнитивная ономасиология. Киев: Издательство украинского фитосоциологического центра.

Serhiyenko, V.L. (2016). Linguocultural concepts Pride and Nobility in the British worldview. Synopsis for thesis for the candidate degree in philology. Speciality 10.02.04 - Germanic languages. Chernivtsi: Yuriy Fed'kovych Chernivtsi National 
University. / Serhiyenko V.L. Linhvokul'turni kontsepty Pride i Nobility u brytanskij movnij kartyni svitu. Avtoreferat dysertatsiyi na zdobuttya vchenoho stupenya kandydata filolohichnykh nauk. Spetsial'nist' 10.02.04 - hermans'ki movy. Chernivtsi: Chernivets'kyj universytet imeni Yu. Fed'kovycha. / Сергієнко В.Л. Лінгвокультурні концепти Pride i Nobility у британській мовній картині світу. Автореферат дисертації на здобуття наукового ступеня кандидата філологічних наук. Спеціальність 10.02.04 - германські мови. Чернівці: Чернівецький національний університет імені Ю. Федьковича.

Shekhovtseva, T.M. (2011). The verbalization of the concept "power" in the modern English language. Thesis for the candidate degree in philology. Speciality 10.02.04Germanic languages. Belgorod: Belgorod National Research University. I Shekhovtseva T.M. Verbalizatsiya kontsepta "sila" $v$ sovremennom anglijskom yazyke. Dissertatsiya na soiskaniye uchyonoj stepeni kandidata filologicheskikh nauk. Spetsial'nost' 10.02.04 - germanskiye yazyki. Belgorod: Belgorodskij gosudarstvennyj natsional'nyj issledovatel'skij universitet. / Шеховцева Т.М. Вербализация концепта "сила" в современном английском языке. Диссертация на соискание ученой степени кандидата филологических наук. Специальность 10.02.04 - германские языки. Белгород: Белгородский государственный национальный исследовательский университет.

Smith, L.J. (1999). The awakening. New York: HarperCollins Publishers.

Snytko, O.S. (2008). The codes of culture in the language objectivization of reality. In Studia linguistica, 1, p. 115-121. / Snytko O.S. Kody kul'tury u movnij obyektyvatsiyi dijsnosti. In Studiya linguistica, 1, s. 115-121. / Снитко О.С. Коди культури у мовній об'єктивації дійсності. In Studia linguistica, 1, с. 115-121.

Stepanov, Yu.S. (2004). Constants: The dictionary of Russian culture. $3^{\text {rd }}$ ed. Moscow: Academic project. / Stepanov Yu.S. Konstanty: Slovar' russkoj kultury. 3 izd. Moskva: Akademicheskij proekt. / Степанов Ю.С. Константы: Словарь русской культурыл. 3-е изд. Москва: Академический проект.

Stoker, B. (1994). Dracula. England: Penguin books. 
Turchenko, V.O. (2014). Cognitive-communicative characteristics of the concept MODESTY in the English speaking discourse of the $14^{\text {th }}-21^{\text {st }}$ centuries. Synopsis for thesis for the candidate degree in philology. Speciality 10.02.04 - Germanic languages. Kharkiv: Kharkiv National V.N. Karazin University. / Turchenko V.O. Kohnityvnokomunikatyvni kharakterystyky kontseptu SKROMNIST'v anhlomovnomy dyskursi XIV - XXI stolit'. Avtoreferat dysertatsiyi na zdobuttya vchenoho stupenya kandydata filolohichnykh nauk. Spetsial'nist' 10.02.04 - hermans'ki movy. Kharkiv: Kharkivs'kyj natsional'nyj uníversytet im. V.N. Karazína. / Турченко B.O. Когнітивнокомунікативні характеристики концепту СКРОМНІСТЬ в англомовному дискурсі XIV-XXI століть. Автореферат дисертації на здобуття наукового ступеня кандидата філологічних наук. Спеціальність 10.02.04 - германські мови. Харків: Харківський національний університет імені В.Н. Каразіна.

The etymological dictionary of the English language. Available at: https://www.etymonline.com

Uberman, A. (2016). Death in metaphorical language. In Lege artis. Language yesterday, today, tomorrow. The journal of University of SS Cyril and Methodius in Trnava. Warsaw: De Gruyter Open, I (2), p. 171-211. DOI: 10.1515//lart-2016-0013 Uberman, A. (2018). Frame analysis of the concept of death across cultures. In Lege artis. Language yesterday, today, tomorrow. The journal of University of SS Cyril and Methodius in Trnava. Warsaw: De Gruyter Open, 2018, III (1), June 2018, p. 417-447. DOI: 10.2478/lart-2018-0011

Vatsuro, V.E. (2002). The Gothic novel in Russia. Moscow: New literature education. / Vatsuro V.E. Goticheskij roman v Rossii. Moskva: Novoye literaturnoye obrazovaniye. I Вацуро В.Э. Готический роман в России. Москва: "Новое литературное образование".

Wierzbicka, A. (2010). Experience, evidence, and sense: The hidden cultural legacy of English. Oxford: Oxford University Press.

Wierzbicka, A. (2014). Imprisoned in English: The hazards of English as a default language. Oxford: Oxford University Press. 
Zhabotyns'ka, S.A. (2006). The possessive construction and conceptual transforms. In Language. Human. World, p. 178-192. / Zhabotyns'ka S.A. Posesyvna konstruktsiya i kontseptual'ni transformy. In Mova. Lyudyna. Svit, s. 178-192. / Жаботинська C.A. Посесивна конструкція і концептуальні трансформи. In Мова. Людина. Свiт, c. $178-192$.

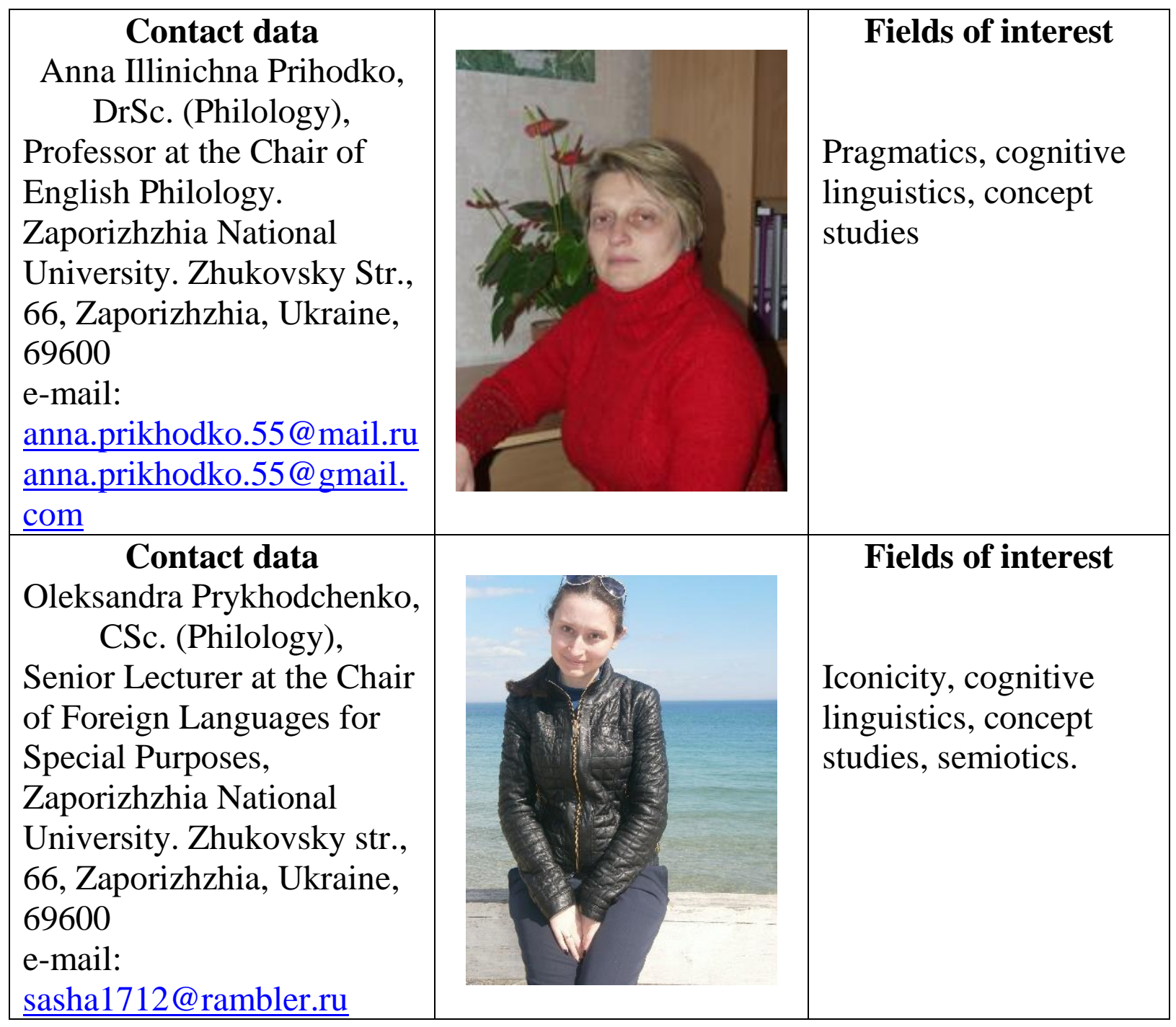

\section{Résumé}

The Gothic worldview is understood as a manifestation of the environment's reflection in peoples' thoughts, which shows the perception of real and unreal / supernatural worlds in their symbiosis and determines the human's role in it. The representation of the result of interrelation between fantasy and the real world in general, and the behavior of the human in unusual situations in particular is the focal aim of Gothic 
culture. LIFE and DEATH are the universal concepts of the culture, which occupy an important place both in the linguistic and in the Gothic worldview. From the linguistic point of view these concepts are extremely up-to-date, taking into consideration their role in the world's depiction. They create a binary structure and are an indivisible unit, each element of which is valuable. It was proved that the objectivization of the concepts of LIFE and DEATH can be shown most fully in the form of frame, the main structural elements of which are ACTANTS, PREDICATES, QAUNTIFIERS, PLACE, and TIME. All parts are defined with a great amount of verbalizations, which affirm the high level of usage of the concepts under investigation. The frame structures of the concepts of LIFE and DEATH show their differences, which are manifested in the understanding of LIFE as a real, positive, specific phenomenon, which is characterized by certain duration, and DEATH, at the same time, is perceived as an unreal, abstract phenomenon, which exists during a very short period of time and is determined rather negatively. But the existence of the sphere of UNEXISTENCE / UNDEAD, which is situated at the edge of the two worlds, and, thus, represents the place, where unalive but active, functioning mystical creatures vampires, who cross this edge, exist, and shows the connection between the two worlds, which are completely different by their nature, but are interrelated in Gothic linguoculture.

Key words: concept, frame, frame structure, worldview, the Gothic novel, the Gothic worldview.

Article was received by the editorial board 27.05.18;

Reviewed 14.08.18. and 28.08.18.

Similarity Index $1 \%$ 